\title{
A green synthesis of nitrones from diamino glyoxime using aldehydes and ketones
}

\author{
Abolghasem Moghimi • Rahim Hosseinzadeh Khanmiri • \\ Ahmad Shaabani • Homayoon Hamadani
}

Received: 15 September 2012/ Accepted: 20 January 2013/Published online: 6 February 2013

(C) The Author(s) 2013. This article is published with open access at Springerlink.com

\begin{abstract}
The reaction of diaminoglyoxime with aldehyde and ketone derivatives in the presence of $p$-toluene sulphonic acid in $\mathrm{H}_{2} \mathrm{O}-\mathrm{MeOH}$ mixture at room temperature afforded nitrone derivatives in high yields within 10-140 min. The applicability of ketones in this reaction for the preparation of novel nitrones has been verified. The effect of the temperature on the stability of the structural isomers of the products has been studied by NMR as well. The results showed that, at high temperatures only one product could be observed. The nature of solvent and catalyst were evaluated and found that the strong acids $\mathrm{H}_{2} \mathrm{SO}_{4}$ and $\mathrm{CF}_{3} \mathrm{SO}_{3} \mathrm{H}$ in protic solvent $\mathrm{CH}_{3} \mathrm{OH}$ work well while neither $\mathrm{CH}_{3} \mathrm{SO}_{3} \mathrm{H}$ in protic solvent nor $p$-toluene sulphonic acid in aprotic solvents toluene and THF perform the same reactions.
\end{abstract}

Keywords Nitrones - Diaminoglyoxime - Benzaldehyde · Cyclohexanone $\cdot$ Condensation $\cdot$ Acid catalyst

\section{Introduction}

Nitrones as the 1,3-dipolar species are valuable intermediates in organic synthesis [1]. Thermal cycloaddition reactions of nitrones with multiple bond systems is an efficient strategy for providing various heterocyclic five-

A. Moghimi $(\bowtie) \cdot$ R. H. Khanmiri · H. Hamadani

Department of Chemistry, Faculty of Science,

Imam Hossein University, Tehran, Iran

e-mail: samoghimi@yahoo.com

R. H. Khanmiri · A. Shaabani

Department of Chemistry, Faculty of Science,

University of Shahid Beheshti,

Tehran, Iran membered ring systems [2-5]. On the other hand, they are source of new heterocyclic compound via ring opening reactions [6-8]. Under facial concerted $\left[{ }_{n} 4_{s}+{ }_{n} 2_{s}\right]$ cycloaddition reaction, nitrones react with acetylenes and olefins to yield isoxazolines and isoxazolidines, respectively. Furthermore, due to the stability of resulting nitroxide radicals and ease of chemical modification [9], nitrones have important biological activity [10-12]. Nitrones are not only useful to understand age-related disease processes but also serendipitously have proven to be candidate for therapeutics in some cases [13]. A number of reports have appeared on the chemistry of 1,3-dipolar species, with special emphasis on their cycloaddition reaction with multiple bonds [14]. The cycloadducts of di- and tri-arylimidazoline-3-oxides [15] with a variety of dipolarophiles [16-21] give interesting biologically active heterocyclic compounds [22]. The 1, 3-dipolar cycloaddition of imidazolin-3-oxides was shown to proceed regio- and diasteroselectivity and interesting reactions of these adducts under various conditions such as the double cis elimination they undergo in the presence of dialkylamines was reported $[23,24]$.

The most common procedures for the preparation of nitrones include oxidation of secondary amines or $\mathrm{N}, \mathrm{N}$ disubstituted hydroxylamine or condensation reaction between aldehydes or ketones with $N$-monosubstituted hydroxylamines [25, 26]. To the best of our knowledge, there are two known cases in the literature reported by G-Q Chen et al. [27, 28] in which 3,4-diaminoglyoxime, DAG, has acted as amine source for the synthesis of nitrones. In those cases the reaction of benzaldehyde derivatives and DAG has been carried out in anhydrous ethanol in the presence of $p$-toluene sulphonic acid ( $p$-TSA) at $55-65{ }^{\circ} \mathrm{C}$ within 6-28 h. Herein, we wish to extend the previously published methodology for the preparation of novel 
nitrones from DAG and cyclic or acyclic ketones and modify the reaction conditions for both ketones and aldehydes. Accordingly, a modified green method for the reaction of DAG with both benzaldehydes and ketones is reported in $\mathrm{H}_{2} \mathrm{O} / \mathrm{MeOH}$ mixture at room temperature in the presence of a strong acid for much shorter reaction times.

\section{Results and discussion}

The chemistry of DAG is of great interest because of the fact that it involves two different reactive functional groups, amine and oxime, that have been repeated twice. One or more functional groups in DAG may react, as expected, with other appropriate functional groups such as aldehydes in different manners and, therefore, totally different products may result. From the theoretical point of view, DAG can perform condensation reaction with aldehyde and ketone in a number of ways. It can react, for instance, (1) in 2:1 molar ratio to get a bis-Schiff bases (I, IV), (2) in 1:1 molar ratio between two $\mathrm{NH}_{2}$ of DAG and $-\mathrm{COH}$ to reach five-membered ring heterocycles (II, V) and (3) in 1:1 molar ratio between $\mathrm{NH}_{2}$ and oxime functional groups of DAG and - $\mathrm{COH}$ to obtain nitrones (III, VI) as shown in Scheme 1.<smiles>N=C(O)C(=O)N=CBr</smiles>

(I)

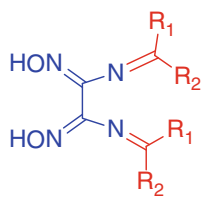

(v)

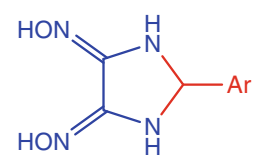

(II)<smiles>[R]C1(Br)NC(=NO)C(=NO)N1</smiles>

(IV)

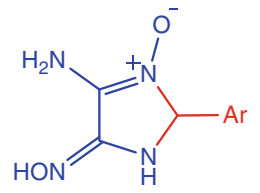

(III)

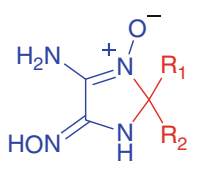

(VI)
Scheme 1 Three logically expected products for each of the reaction of DAG with aldehyde and ketone derivatives
However, it was found that the nitrones are prepared in the presence of $p$-TSA, as catalyst, under the reaction conditions applied, as shown in Scheme 2.

The condensation reaction of DAG was initially performed in the absence of $p$-TSA using benzaldehyde or cyclohexanone in methanol-water (30:70) mixture at room temperature and the progress of the reaction was monitored by TLC. A slow condensation reaction was noticed. Then, they were performed in the presence of $p$-TSA and, after the completion of the reaction, the corresponding nitrones were isolated as white precipitate within 10-140 $\mathrm{min}$ in 83 and $95 \%$, respectively. It became clear to us that the anhydrous condition is not mandatory, as was applied earlier, and the reaction works well in $\mathrm{H}_{2} \mathrm{O} / \mathrm{MeOH}$ solvent at room temperature. The same procedure was successfully applied to the other aldehydes (2) and ketones (4) and the expected nitrones 3a-i and 5a-e were isolated in good yields (Table 1). It was found that higher yields could be achieved for the aromatic aldehyde derivatives involving electron donating group, as shown in Table 1.

Considering the proposed mechanism by G-Q Chen et al. for the reaction of DAG and benzaldehyde derivatives, we suggest a similar reaction mechanism for ketones as shown in the scheme 3. Firstly, the protonated carbonyl in ketone derivatives is attacked by the nitrogen atom of one of the amino groups of 3,4-diaminoglyoxime $\mathbf{1}$, and the $\mathrm{C}=\mathrm{N}$ functional group is formed by deprotonation and dehydration. Subsequently, the nitrogen in the newly formed $\mathrm{C}=\mathrm{N}$ bond is protonated, followed by the nucleophilic attach by the oxime nitrogen atom, and the fivemembered heterocyclic ring is formed. By deprotonation, the final products $\mathbf{5}(\mathbf{a}-\mathbf{e})$ are obtained.

The structure of nitrones $\mathbf{3}(\mathbf{a}-\mathbf{i})$ and $\mathbf{5}(\mathbf{a}-\mathbf{e})$ were determined by IR, ${ }^{1} \mathrm{HNMR},{ }^{13} \mathrm{CNMR}$ and mass spectra. In the IR spectra 3(a-i) strong absorption bands at 2,883-2,892 $\mathrm{cm}^{-1}$ can be observed which should be assigned to the $\mathrm{C}-\mathrm{H}$ in imidazole ring and $1,450-1,650 \mathrm{~cm}^{-1}$ for the benzene ring. In addition, in the ${ }^{13} \mathrm{C}$ spectra of nitrones $\mathbf{5}(\mathbf{a}-\mathbf{e})$ characteristic peaks in the 80-100 ppm region can be observed, which

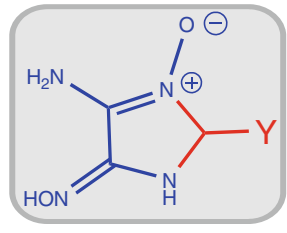

3a-i

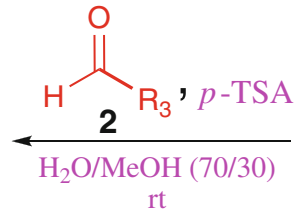

$\mathrm{rt}$

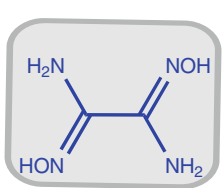

1

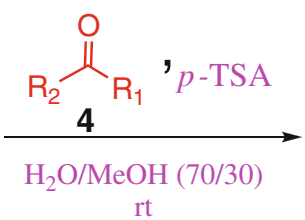

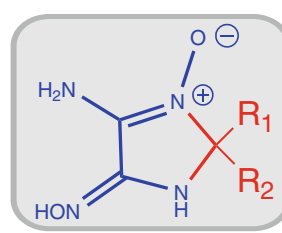

5a-e

$\mathbf{R}_{3}: 3-\mathrm{MeC}_{6} \mathrm{H}_{4}, \mathrm{C}_{6} \mathrm{H}_{5}, 4-\mathrm{MeOC}_{6} \mathrm{H}_{4}, 4-\mathrm{ClC}_{6} \mathrm{H}_{4}, 2-\mathrm{MeOC}_{6} \mathrm{H}_{4}, 5-\mathrm{Br}-2-\mathrm{HOC}_{6} \mathrm{H}_{4}, 2-\mathrm{ClC}_{6} \mathrm{H}_{4}, 3-\mathrm{MeOC}_{6} \mathrm{H}_{4}, \mathrm{CH}_{3}$

4: Cyclopentanone, Cyclohexanone, Cycloheptanone, 4-tert-butyl cyclohexanone, acetone

Scheme 2 Cyclic functionalized nitrones obtained in the reaction of DAG with aldehydes and ketones 
Table 1 Reaction conditions for the synthesis of nitrones $\mathbf{3 a - i}$ and 5a-e in $\mathrm{H}_{2} \mathrm{O} / \mathrm{MeOH}(70 / 30)$ solvent at room temperature

\begin{tabular}{lllrl}
\hline Entry & Comp. & $\mathrm{R}_{3}$ & $\begin{array}{r}\text { Time } \\
(\mathrm{min})\end{array}$ & $\begin{array}{l}\text { Yield } \\
(\%)^{\mathrm{a}}\end{array}$ \\
\hline 1 & $3 \mathrm{a}$ & $3-\mathrm{MeC}_{6} \mathrm{H}_{4}$ & 120 & 90 \\
2 & $3 \mathrm{~b}$ & $\mathrm{C}_{6} \mathrm{H}_{5}$ & 120 & 83 \\
3 & $3 \mathrm{c}$ & $4-\mathrm{MeOC}_{6} \mathrm{H}_{4}$ & 60 & 84 \\
4 & $3 \mathrm{~d}$ & $4-\mathrm{ClC}_{6} \mathrm{H}_{4}$ & 10 & 81 \\
5 & $3 \mathrm{e}$ & $2-\mathrm{MeOC}_{6} \mathrm{H}_{4}$ & 15 & 69 \\
6 & $3 \mathrm{f}$ & $5-\mathrm{Br}_{2}-\mathrm{HOC}_{6} \mathrm{H}_{4}$ & 110 & 62 \\
7 & $3 \mathrm{~g}$ & $2-\mathrm{ClC}_{6} \mathrm{H}_{4}$ & 60 & 70 \\
8 & $3 \mathrm{~h}$ & $3-\mathrm{MeOC}_{6} \mathrm{H}_{4}$ & 30 & 71 \\
9 & $3 \mathrm{i}$ & $\mathrm{CH}_{3}$ & 140 & 65 \\
10 & $5 \mathrm{a}$ & Cyclopentanone $_{10}$ & 120 & 90 \\
11 & $5 \mathrm{~b}$ & Cyclohexanone & 25 & 95 \\
12 & $5 \mathrm{c}$ & Cycloheptanone & 100 & 88 \\
13 & $5 \mathrm{~d}$ & 4-tert-butyl & 90 & 94 \\
& & cyclohexanone & 70 & 85 \\
\hline
\end{tabular}

Reaction conditions: DAG $(1.0 \mathrm{mmol})$, aldehyde or ketone (1.2 mmol), $p$-TSA (3 mol \%), $\mathrm{MeOH} / \mathrm{H}_{2} \mathrm{O}(30 / 70)(3 \mathrm{~mL})$, room temperature

a Isolated yield

confirms the presence of spiro carbon of the corresponding nitrones.

The ${ }^{1} \mathrm{HNMR}$ spectrum of $\mathbf{3 b}$ before heating at $100{ }^{\circ} \mathrm{C}$ exhibited characteristic signals for $\mathrm{CH}$ imidazole ring at 5.62, $5.77 \mathrm{ppm}, \mathrm{NH}_{2}$ at $6.40,6.49 \mathrm{ppm}, \mathrm{NH}$ at 7.57 , $7.83 \mathrm{ppm}, \mathrm{NOH}$ at $10.02,10.23 \mathrm{ppm}$ and $\mathrm{CH}$ aryl hydrogens in the 7.30-7.56 ppm regions. In the ${ }^{13} \mathrm{CNMR}$ spectra, aromatic carbon atoms resonated at 126.9, 127.0, 127.2, 128.1, 128.9, 129.2, 129.4, 129.7, 129.9, $131.3 \mathrm{ppm}$. Other carbons were observed at 140.1, 141.9 and 145.4 and $152.0 \mathrm{ppm}$. It is worth to note that the expected peak numbers in ${ }^{13} \mathrm{CNMR}$ spectra are almost double in most of the cases.

The ${ }^{1}$ HNMR spectrum of $\mathbf{5 b}$ exhibited characteristic $\mathrm{CH}_{2}$ signals for cyclohexane ring in the 1.19-1.67 ppm region, $\mathrm{NH}_{2}$ at $5.47,6.25 \mathrm{ppm}, \mathrm{NH}$ at $6.94,7.76 \mathrm{ppm}$, $\mathrm{NOH}$ at $9.91,10.07 \mathrm{ppm}$. In the ${ }^{13} \mathrm{CNMR}$ spectra, spiro carbon appeared at 83.7, 97.6 ppm and carbons of cyclic

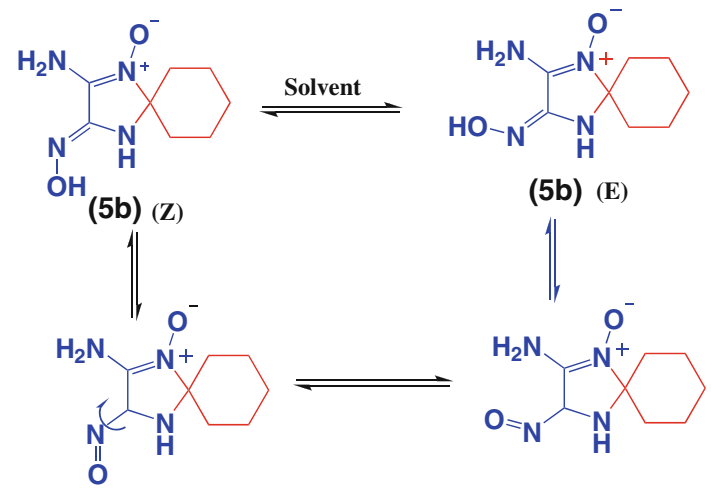

Scheme 4 A proposed Z-E isomerization pathway for $\mathrm{HO}-\mathrm{N}=\mathrm{C}-\mathrm{NH}$ segment in $\mathbf{5 b}$

cyclohexane resonated at 21.2, 22.4, 24.1, 24.3, 34.7, $35.8 \mathrm{ppm}$. Other carbons were observed at 135.5, 141.8, 143.7 and $150.5 \mathrm{ppm}$. As noticed for the nitrone products obtained from aldehyde derivatives, the number of ${ }^{13} \mathrm{C}$ peak observed for the nitrones resulted from ketones are almost double of those expected in the static ${ }^{13} \mathrm{C}$ NMR spectra. This might be due to the $\mathrm{Z}-\mathrm{E}$ isomerization of $\mathrm{HO}-\mathrm{N}=\mathrm{C}-\mathrm{NH}$ segment via either tautomerization followed by rotation or nitrogen inversion of the hydroxyimino group shown for 5b. (Scheme 4) Similar isomerization pathway could be considered for the other nitrone derivatives $\mathbf{3}$ and $\mathbf{5}$.

To investigate the unexpected number of NMR peaks in the obtained nitrone derivatives, dynamic NMR studies were undertaken. So, the effect of heat treatment on the ${ }^{1} \mathrm{H}$ NMR and ${ }^{13} \mathrm{C}$ NMR spectra was monitored. The ${ }^{1} \mathrm{H}-$ and ${ }^{13} \mathrm{C}$ NMR spectra for $\mathbf{3 b}$ and $\mathbf{5 b}$ showed the presence of two isomers of nitrones at room temperature. The ${ }^{1} \mathrm{H}-$ and ${ }^{13} \mathrm{C}$ NMR spectra were recorded again after heating the samples at $100{ }^{\circ} \mathrm{C}$ for $1 \mathrm{~h}$ and cooling down the sample to room temperature. As shown in Fig. 1 and 2, only one isomer was noticed in each case, after heat treatment. This is probably due to the thermal stability of the Z-isomer over the E-isomer of nitrone [27, 28]. Based on the chemical shifts of the observed peaks, after heat treatment, one can specify which set of peaks in the NMR spectra of Z-E mixtures are due to each of the isomers. This method has
Scheme 3 The plausible mechanism for the formation of 2-amino-3-(hydroxyimino)-1, 4-diazaspiro [4.5]dec-1-ene 1-oxide from the reaction of cyclohexanone and DAG
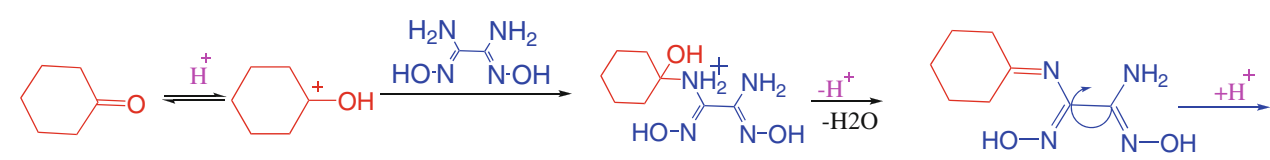

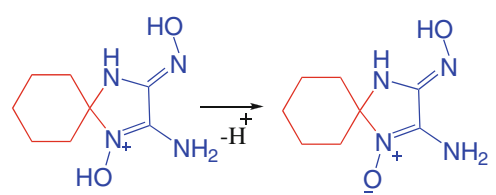



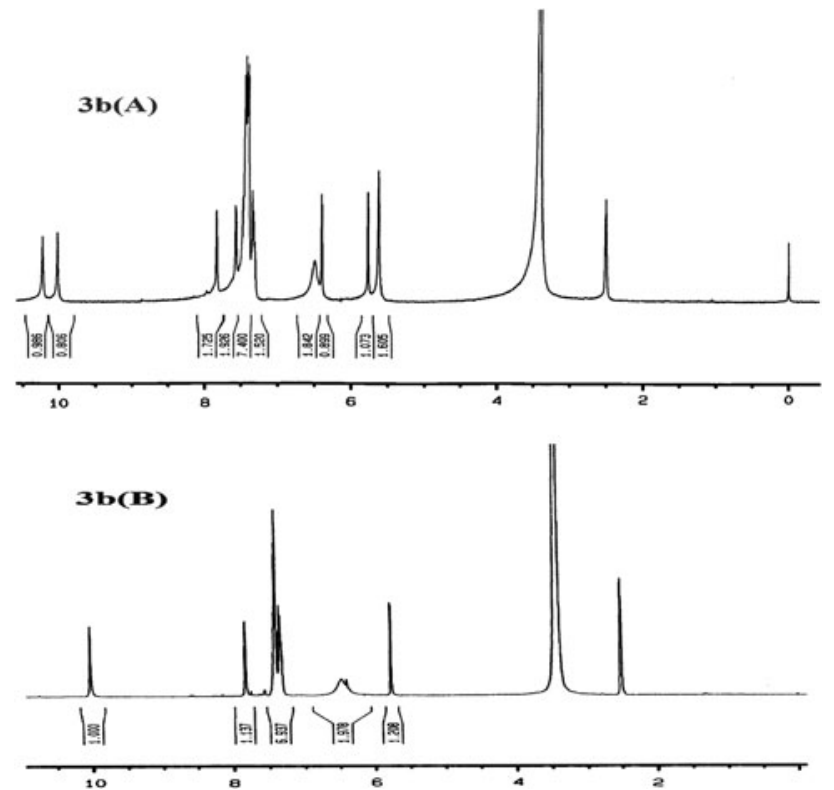

Fig. $1{ }^{1} \mathrm{HNMR}$ spectra of $\mathbf{3 b}$ before (a) and after (b) heat treatment at $100{ }^{\circ} \mathrm{C}$ for $1 \mathrm{~h}$

been followed to analyze the NMR spectral data in "Experimental" section.

The reaction of aldehyde $\mathbf{2 c}$ and DAG was performed in the various protic and aprotic solvents to evaluate the role of the solvent on the reaction. It was found that $\mathrm{MeOH}$ and $\mathrm{H}_{2} \mathrm{O}$ showed good and low yields, respectively, and their mixtures showed less yields than $\mathrm{MeOH}$ (Table 2), while no progress was detected in THF or toluene even after $24 \mathrm{~h}$.

In addition, the reaction of $2 \mathrm{c}$ and $\mathrm{DAG}$ in $\mathrm{MeOH} / \mathrm{H}_{2} \mathrm{O}$ solvent was investigated in the presence of other acids such as $\mathrm{H}_{2} \mathrm{SO}_{4}, \mathrm{CF}_{3} \mathrm{SO}_{3} \mathrm{H}$ and $\mathrm{CH}_{3} \mathrm{SO}_{3} \mathrm{H}$ as the catalyst (Table 3). It was found that the $\mathrm{H}_{2} \mathrm{SO}_{4}$ and $\mathrm{CF}_{3} \mathrm{SO}_{3} \mathrm{H}$ work better than $p$-TSA in a much shorter period of time while the weaker acid $\mathrm{CH}_{3} \mathrm{SO}_{3} \mathrm{H}$ was found to be unreactive.

\section{Conclusions}

In summary, the present procedure provides an example of green chemistry methodology for the synthesis of 2,5-dihydro- $1 H$-imidazole 3-oxides and 1,4-diazaspiro[4.n]dec-1-ene 1-oxides ( $n=4-6)$ involving an amine and an oxime functional groups at 4 and 5 positions in protic solvent $\mathrm{MeOH}$ or $\mathrm{H}_{2} \mathrm{O} / \mathrm{MeOH}$ with high yields within 1-2 h using p-TSA, $\mathrm{H}_{2} \mathrm{SO}_{4}$ or $\mathrm{CF}_{3} \mathrm{SO}_{3} \mathrm{H}$ as catalyst. The resulting nitrones are highly potent for the preparation of fused ring heterocyclic compounds by the application of 1,3-dipolar cycloaddition reactions. In addition, the amine and oxime functional groups in the nitrone derivatives can be applied for the generation of new fused ring
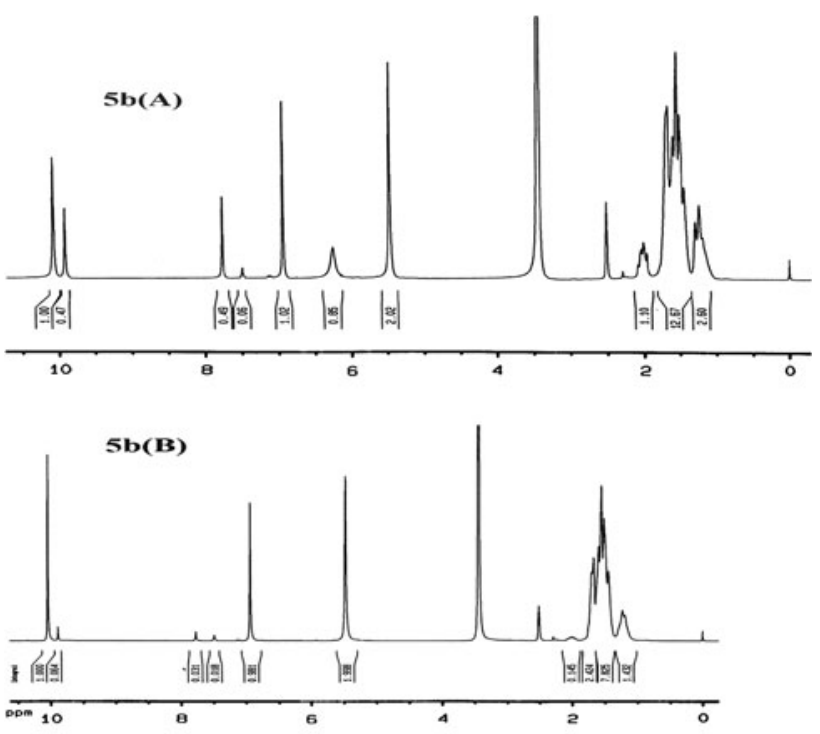

$5 \mathbf{b}(\mathrm{A})$
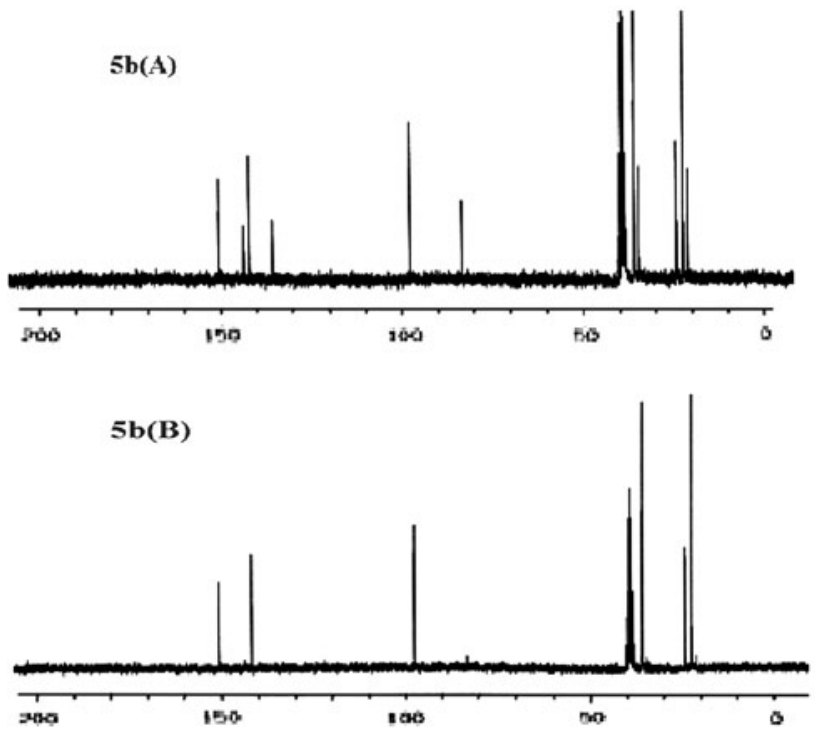

Fig. $2{ }^{1} \mathrm{HNMR}$ and ${ }^{13} \mathrm{CNMR}$ spectra of $\mathbf{5 b}$ before $\mathbf{a}$ and after $\mathbf{b}$ heat treatment at $100{ }^{\circ} \mathrm{C}$ for 1 hour

Table 2 Solvent effect on the reaction yield for the condensation reaction of DAG and $2 \mathrm{c}$ in the presence of $p$-TSA

\begin{tabular}{llll}
\hline Entry & Solvent & Time & Yield $(\%)^{\mathrm{a}}$ \\
\hline 1 & $\mathrm{H}_{2} \mathrm{O}$ & $80 \mathrm{~min}$ & 20 \\
2 & $\mathrm{MeOH}$ & $45 \mathrm{~min}$ & 88 \\
3 & $\mathrm{EtOH}$ & $24 \mathrm{~h}$ & 10 \\
4 & $\mathrm{MeOH} / \mathrm{H}_{2} \mathrm{O}(50 / 50)$ & $40 \mathrm{~min}$ & 85 \\
5 & $\mathrm{MeOH} / \mathrm{H}_{2} \mathrm{O}(30 / 70)$ & $60 \mathrm{~min}$ & 84 \\
6 & $\mathrm{MeOH} / \mathrm{H}_{2} \mathrm{O}(20 / 80)$ & $60 \mathrm{~min}$ & 78 \\
7 & $\mathrm{THF}$ & $24 \mathrm{~h}$ & Trace \\
8 & Toluene & $24 \mathrm{~h}$ & 0 \\
\hline
\end{tabular}

Reaction conditions: DAG $(1.0 \mathrm{mmol}), 4-\mathrm{MeOC}_{6} \mathrm{H}_{4}(1.2 \mathrm{mmol})$, $p$-TSA $(3 \mathrm{~mol} \%)$, room temperature

a Isolated yield 
Table 3 The effect of various acids on the reaction time and yield

\begin{tabular}{llcl}
\hline Entry & Acid & Time $(\mathrm{min})$ & Yield $(\%)^{\mathrm{a}}$ \\
\hline 1 & $\mathrm{H}_{2} \mathrm{SO}_{4}$ & 3 & 89 \\
2 & $\mathrm{CF}_{3} \mathrm{SO}_{3} \mathrm{H}$ & 2 & 90 \\
3 & $\mathrm{CH}_{3} \mathrm{SO}_{3} \mathrm{H}$ & 60 & - \\
4 & p-TSA & 60 & 84 \\
\hline
\end{tabular}

Reaction conditions: DAG (1.0 mmol), $4-\mathrm{MeOC}_{6} \mathrm{H}_{4}(1.2 \mathrm{mmol})$, acid (3 mol \%), $\mathrm{MeOH} / \mathrm{H}_{2} \mathrm{O}(30 / 70)(3 \mathrm{~mL})$, room temperature

a Isolated yield

heterocycles. Therefore, they are expected to find important applications in the synthesis of novel fused ring systems. This proposal is under investigation and the results will be published elsewhere.

In comparison to the previously reported methodology for the preparation of the under-discussion nitrones there are some advantages for the current modification including (1) synthesis of a new class of nitrones with the ketones, (2) application of a green procedure by the usage of $\mathrm{H}_{2} \mathrm{O}$ as solvent, (3) improvement of the reaction yields, (4) application of mild reaction conditions and (5) avoiding long reaction times. Finally, the effect of the Heat treatment on the stability of the structural isomers of the products has been studied as well.

\section{Experimental}

All the reagent and solvents were obtained from Merck (Germany) and were used without further purification. DAG was prepared according to the literature procedure $^{17}$. Melting points were measured on an Electrothermal 9100 apparatus. Mass spectra were recorded on a FINNIGAN-MAT 8430 mass spectrometer operating at an ionization potential of $70 \mathrm{eV} .{ }^{1} \mathrm{H}$ and ${ }^{13} \mathrm{C}$ NMR spectra were recorded on a Bruker DRX-300 Advance spectrometer at 300.13 and $75.47 \mathrm{MHz}$, respectively. NMR spectra were obtained in DMSO- $\mathrm{d}_{6}$ using TMS as internal standard.

General procedure for the preparation of nitrones

3,4-Diaminoglyoxime $(0.12 \mathrm{~g}, 1 \mathrm{mmol})$, benzaldehyde derivatives $(1.2 \mathrm{mmol})$ or ketones $(1.2 \mathrm{mmol})$ and $p$-toluene sulphonic acid ( $p$-TSA) $(0.034 \mathrm{~g}, 0.2 \mathrm{mmol})$ were added to a solution of water:methanol (70:30, $5 \mathrm{ml})$, and the mixture was stirred at room temperature for appropriate time. The progress of the reaction was monitored by TLC (ethyl acetate/n-hexane 7:3). Then, the reaction mixture was filtered off and the precipitate was washed with methanol-water and dried.
4-Amino-5-(hydroxyimino)-2-(4-methylphenyl)-2,5dihydro-1H-imidazole3-oxide( $3 a)$

(90\%) white solid, mp $209-210{ }^{\circ} \mathrm{C}$; IR $\left(\mathrm{KBr}, \mathrm{cm}^{-1}\right)$ : 3,358, 3,242 $\left(\mathrm{NH}_{2}\right), 3,158,3,097(\mathrm{OH}), 2,883$ (CH-Imidazole), 1,716, 1,683 $(\mathrm{C}=\mathrm{N}), 1,602,1,454$ (benzene ring), $1,353(\mathrm{~N}=\mathrm{O}), 1,226(\mathrm{C}-\mathrm{N}), 933,921(\mathrm{~N}-\mathrm{O})$.

$\mathrm{Z}$ and $\mathrm{E}$ isomer: ${ }^{1} \mathrm{HNMR}\left(250 \mathrm{MHz}, \mathrm{DMSO}-d_{6}\right): 3.39$ (s, 3H, $\mathrm{CH}_{3}$ ), 5.60, 5.71 (s, H, CH-Imidazole), 6.34, 6.51 (s, $\mathrm{H}, \mathrm{NH}_{2}$ ), 7.32-7.44 (m, H-Ar), 7.49, 7.76 (s, H, NH), 9.98, $10.20(\mathrm{~s}, \mathrm{H}, \mathrm{NOH}) \mathrm{ppm} ;{ }^{13} \mathrm{CNMR}\left(62.5 \mathrm{MHz}, \mathrm{DMSO}-d_{6}\right)$ : 81.2, 93.8, 127.2, 128.0, 129.1, 129.3, 134.2, 137.1, 139.0, $141.9,144.1,152.0 \mathrm{ppm}$.

Z-isomer: ${ }^{1} \mathrm{HNMR}\left(250 \mathrm{MHz}, \mathrm{DMSO}-d_{6}\right): 3.39$ (s, $3 \mathrm{H}$, $\mathrm{CH}_{3}$ ), 5.60 (s, H, CH-Imidazole), $6.35\left(\mathrm{~s}, \mathrm{H}, \mathrm{NH}_{2}\right.$ ), 7.33-7.47 (m, H-Ar), 7.47 (s, H, NH), 10.20 (s, H, NOH) ppm; ${ }^{13} \mathrm{CNMR}\left(62.5 \mathrm{MHz}\right.$, DMSO- $\left.d_{6}\right)$ : 94.8, 127.8, 128.6, $129.3,129.5,137.6,139.9,142.9,153.0 \mathrm{ppm}$.

\section{4-Amino-5-(hydroxyimino)-2-phenyl-2,5-dihydro- $1 \mathrm{H}$ -} imidazole 3-oxide $(3 b)$

$(83 \%)$ white solid, $\mathrm{mp} 202-203{ }^{\circ} \mathrm{C}$; $\operatorname{IR}\left(\mathrm{KBr}, \mathrm{cm}^{-1}\right)$ : 3,355, 3,251 $\left(\mathrm{NH}_{2}\right), 3,183,3,097(\mathrm{OH}), 2,884$ (imidazole $\mathrm{C}-\mathrm{H}), 1,716,1,682(\mathrm{C}=\mathrm{N}), 1,603,1,458$ (benzene ring), $1,360(\mathrm{~N}=\mathrm{O}), 1,226(\mathrm{C}-\mathrm{N}), 933,921(\mathrm{~N}-\mathrm{O}) ; \mathrm{MS}: \mathrm{m} / \mathrm{e}(\%)$ $206\left(\mathrm{M}^{+}, 10\right), 189(\mathrm{M}-\mathrm{NH} 3,9), 161(20), 139(80), 105$ $\left(\mathrm{C}_{6} \mathrm{H}_{5} \mathrm{CHNH}\right.$, base peak, 100), 77 (90), 69 (40), 65 (50).

$\mathrm{Z}$ and $\mathrm{E}$ isomer: ${ }^{1} \mathrm{HNMR}\left(250 \mathrm{MHz}\right.$, DMSO- $\left.d_{6}\right): 5.62$, 5.77 (s, H, CH-Imidazole), 6.40, $6.49\left(\mathrm{~s}, \mathrm{H}, \mathrm{NH}_{2}\right), 7.30-$ 7.56 (m, H-Ar), 7.57, 7.83 (s, H, NH), 10.02, 10.23 (s, H, $\mathrm{NOH}) \mathrm{ppm} ;{ }^{13} \mathrm{C}$ NMR $\left(62.5 \mathrm{MHz}, \mathrm{DMSO}-d_{6}\right): 80.2,93.8$, $126.9,127.0,127.2,128.1,128.9,129.2,129.4,129.7$, 129.9, 131.3, 140.1, 141.9, 145.4, $152 \mathrm{ppm}$.

Z-isomer: ${ }^{1} \mathrm{HNMR}\left(250 \mathrm{MHz}, \mathrm{DMSO}-d_{6}\right): 5.75(\mathrm{~s}, \mathrm{H}$, CH-Imidazole), 6.52 (s, H, $\mathrm{NH}_{2}$ ), 7.43-7.75 (m, H-Ar), $7.87(\mathrm{~s}, \mathrm{H}, \mathrm{NH}), 10.25$ (s, H, NOH) ppm. ${ }^{13} \mathrm{C}$ NMR (62.5 MHz, DMSO- $\left.d_{6}\right)$ : 92.6, 126.6, 127.2, 128.7, 129.1, $129.2,129.5,129.9,132.3,143.6,152.3 \mathrm{ppm}$.

\section{4-Amino-5-(hydroxyimino)-2-(4-methoxyphenyl)-2,5-} dihydro-1H-imidazole 3-oxide (3c)

(84 \%) white solid, mp 196-198 ${ }^{\circ} \mathrm{C}$; $\mathrm{IR}\left(\mathrm{KBr}, \mathrm{cm}^{-1}\right)$ : 3,395, 3,311 $\left(\mathrm{NH}_{2}\right), 3,167,3,097(\mathrm{OH}), 2,891$ (CH-Imidazole), $1,716,1,694(\mathrm{C}=\mathrm{N}), 1,613,1,515$ (benzene ring), 1,372 $(\mathrm{N}=\mathrm{O}), 1,248(\mathrm{C}-\mathrm{N}), 937,923(\mathrm{~N}-\mathrm{O})$.

$\mathrm{Z}$ and $\mathrm{E}$ isomer: ${ }^{1} \mathrm{HNMR}\left(250 \mathrm{MHz}, \mathrm{DMSO}-d_{6}\right): 3.75$, 3.78 (s, 3H, $\mathrm{CH}_{3}$ ), 5.72, 6.03 (s, H, CH-Imidazole), 6.51, 6.64 (s, $\mathrm{H}, \mathrm{NH}_{2}$ ), 6.96-7.38 (m, H-Ar), 7.38, 7.54 (s, H, NH), 9.94, 10.21 (s, H, NOH) ppm; ${ }^{13} \mathrm{CNMR}\left(62.5 \mathrm{MHz}, \mathrm{DMSO}-d_{6}\right)$ : 55.94, 55.97, 78.9, 88.50, 111.58, 120.68, 127.13, 127.49, $130.81,130.90,142.00,151.83,153.5,157.50 \mathrm{ppm}$. 
Z-isomer: ${ }^{1} \mathrm{HNMR}\left(250 \mathrm{MHz}, \mathrm{DMSO}-d_{6}\right): 3.76(\mathrm{~s}, 3 \mathrm{H}$, $\mathrm{CH}_{3}$ ), 5.71 (s, H, CH-Imidazole), 6.65 (s, $\mathrm{H}, \mathrm{NH}_{2}$ ), 6.94-7.29 (m, H-Ar), 7.40 (s, H, NH), 10.23 (s, H, NOH) ppm; ${ }^{13} \mathrm{CNMR}$ (62.5 MHz, DMSO- $\left.d_{6}\right): 55.44,88.53$, $113.54,121.48,127.17,128.49$, 130.81, 131.90, 142.20, $152.83,157.50 \mathrm{ppm}$.

4-Amino-5-(hydroxyimino)-2-(4-chlorophenyl)-2,5dihydro-1H-imidazole 3-oxide (3d)

(81\%) white solid, $\mathrm{mp} 206-207{ }^{\circ} \mathrm{C}$; IR $\left(\mathrm{KBr}, \mathrm{cm}^{-1}\right)$ : 3,365, 3,239 $\left(\mathrm{NH}_{2}\right), 3,182(\mathrm{OH}), 2,883$ (CH-Imidazole), 1,716, 1,684 $(\mathrm{C}=\mathrm{N}), 1,599,1,455$ (benzene ring), 1,351 $(\mathrm{N}=\mathrm{O}), 1,229(\mathrm{C}-\mathrm{N}), 927(\mathrm{~N}-\mathrm{O})$.

$\mathrm{Z}$ and $\mathrm{E}$ isomer: ${ }^{1} \mathrm{HNMR}\left(250 \mathrm{MHz}, \mathrm{DMSO}-d_{6}\right): 5.60$, 5.81 (s, H, CH-Imidazole), 6.40, 6.72 (s, H, NH $)$, 7.868.28 (m, H-Ar), 8.14, 8.24 (s, H, NH), 10.41, 10.45 (s, H, $\mathrm{NOH}) \mathrm{ppm} ;{ }^{13} \mathrm{CNMR}\left(62.5 \mathrm{MHz}, \mathrm{DMSO}-d_{6}\right): 80.12,92.9$, $128.4,128.7,128.9,129.0,129.2,131.7,134.1,134.2$, 141.8, 147.5, 148.4, 151.9, 166.4 ppm.

Z-isomer: ${ }^{1} \mathrm{HNMR}\left(250 \mathrm{MHz}, \mathrm{DMSO}-d_{6}\right): 5.63$ (s, H, CH-Imidazole), 6.42 (s, H, $\mathrm{NH}_{2}$ ), 7.82-8.23 (m, H-Ar), 8.11 (s, H, NH), 10.36 (s, H, NOH) ppm; ${ }^{13} \mathrm{CNMR}$ (62.5 MHz, DMSO- $\left.d_{6}\right)$ : 92.9, 128.4, 128.7, 128.9, 129.0 $129.4,1,134.2,134.5,142.8,148.4,152.9,167.4$ ppm.

\section{4-Amino-5-(hydroxyimino)-2-(2-methoxyphenyl)-2,5-} dihydro-1H-imidazole 3-oxide (3e)

(69\%) white solid, mp 196-198 ${ }^{\circ} \mathrm{C}$; $\mathrm{IR}\left(\mathrm{KBr}, \mathrm{cm}^{-1}\right)$ : 3,400, 3,264 $\left(\mathrm{NH}_{2}\right), 3,180(\mathrm{OH}), 2,892$ (CH-Imidazole), $1,709,1,687(\mathrm{C}=\mathrm{N}), 1,687,1,469$ (benzene ring), 1,348 $(\mathrm{N}=\mathrm{O}), 1,220(\mathrm{C}-\mathrm{N}), 931(\mathrm{~N}-\mathrm{O})$.

$\mathrm{Z}$ and $\mathrm{E}$ isomer: ${ }^{1} \mathrm{HNMR}\left(250 \mathrm{MHz}, \mathrm{DMSO}-d_{6}\right): 3.77$, 3.79 (s, 3H, $\mathrm{CH}_{3}$ ), 5.49, 5.66 (s, H, CH-Imidazole), 6.04, 6.66 (s, H, $\mathrm{NH}_{2}$ ), 6.98-7.05 (m, H-Ar), 7.23, 7.31 (s, H, $\mathrm{NH}), 10.13,10.17$ (s, H, NOH) ppm; ${ }^{13} \mathrm{CNMR}(62.5 \mathrm{MHz}$, DMSO- $\left.d_{6}\right): 55.11,79.1,88.5,111.6,120.6,127.2,127.5$, $130.8,142.0,151.8,157.5 \mathrm{ppm}$.

Z-isomer: ${ }^{1} \mathrm{HNMR}\left(250 \mathrm{MHz}, \mathrm{DMSO}-d_{6}\right): 3.79$ (s, 3H, $\mathrm{CH}_{3}$ ), 5.51 (s, H, CH-Imidazole), 6.64 (s, H, NH${ }_{2}$ ), 6.957.04 (m, H-Ar), 7.33 (s, H, NH), 10.14 (s, H, NOH) ppm; ${ }^{13} \mathrm{CNMR}$ (62.5 MHz, DMSO- $\left.d_{6}\right)$ : 55.11, 88.5, 111.6, $120.6,125.3,127.2,127.5,128.2,130.8,131.0,142.0$, $148.2,151.8,153.3,157.5 \mathrm{ppm}$.

4-Amino-2-(5-bromo-2-hydroxyphenyl)-5-(hydroxyimino)2,5-dihydro-1H-imidazole 3-oxide (3f)

(62\%) white solid, mp $173-175{ }^{\circ} \mathrm{C} ; \operatorname{IR}\left(\mathrm{KBr}, \mathrm{cm}^{-1}\right)$ : 3,329, 3,285 $\left(\mathrm{NH}_{2}\right), 3,188(\mathrm{OH}), 2,912$ (CH-Imidazole), $1,715,1,685(\mathrm{C}=\mathrm{N}), 1,594,1,495$ (benzene ring), 1,354 $(\mathrm{N}=\mathrm{O}), 1,226(\mathrm{C}-\mathrm{N}), 934(\mathrm{~N}-\mathrm{O})$.
$\mathrm{Z}$ and $\mathrm{E}$ isomer: ${ }^{1} \mathrm{HNMR}\left(250 \mathrm{MHz}, \mathrm{DMSO}-d_{6}\right): 5.63$, 5.97 (s, H, CH-Imidazole), 6.24, 6.36 (s, H, $\mathrm{NH}_{2}$ ), 7.94-8.72 (m, H-Ar, NH), 10.21, 10.35 (s, H, NOH), 12.94, $13.26(\mathrm{~s}, 1 \mathrm{H}, \mathrm{OH}) \mathrm{ppm} ;{ }^{13} \mathrm{CNMR}(62.5 \mathrm{MHz}$, DMSO- $\left.d_{6}\right): 56.50,84.6,93.7,116.7,118.51,120.12$, $121.42,126.5,128.7,129.3,130.7,131.9,142.0,152.0$, 159.4, $161.13 \mathrm{ppm}$.

Z-isomer: ${ }^{1} \mathrm{HNMR}$ (250 MHz, DMSO- $d_{6}$ ): 5.95 (s, H, CH-Imidazole), 6.37 (s, H, $\mathrm{NH}_{2}$ ), 7.86-8.68 (m, H-Ar, $\mathrm{NH}), 10.35$ (s, H, NOH), 13.26 (s, 1H, OH) ppm; ${ }^{13} \mathrm{CNMR}$ $\left(62.5 \mathrm{MHz}, \mathrm{DMSO}-d_{6}\right): 56.61,93.7,128.7,129.3,131.9$, 142.0, 152.0, $159.4 \mathrm{ppm}$.

4-Amino-5-(hydroxyimino)-2-(2-cholorophenyl)-2,5dihydro-1H-imidazole 3-oxide (3 g)

(70\%) white solid, mp 205-207 ${ }^{\circ} \mathrm{C}$; $\operatorname{IR}\left(\mathrm{KBr}, \mathrm{cm}^{-1}\right)$ : 3,364, 3,241 $\left(\mathrm{NH}_{2}\right), 3,184(\mathrm{OH}), 2,883$ (CH-Imidazole), $1,715,1,682(\mathrm{C}=\mathrm{N}), 1,600,1,458$ (benzene ring), 1,353 $(\mathrm{N}=\mathrm{O}), 1,231(\mathrm{C}-\mathrm{N}), 931(\mathrm{~N}-\mathrm{O})$.

Z-isomer: ${ }^{1} \mathrm{HNMR}\left(250 \mathrm{MHz}, \mathrm{DMSO}-d_{6}\right): 6.17$ (s, H, CH-Imidazole), 7.28 (s, H, NH ${ }_{2}$, 7.40-7.46 (m, H-Ar), 8.14 (s, H, NH), 10.24 (s, H, NOH) ppm; ${ }^{13} \mathrm{CNMR}$ $\left(62.5 \mathrm{MHz}, \mathrm{DMSO}-d_{6}\right)$ : 78.1, 127.9, 130.2, 130.4, 131.4, 133.7, 134.0, 139.3, $145.2 \mathrm{ppm}$.

4-Amino-5-(hydroxyimino)-2-(3-methoxyphenyl)-2,5dihydro-1H-imidazole 3-oxide( $3 \mathrm{~h})$

(71\%) white solid, mp $197-199{ }^{\circ} \mathrm{C}$; $\operatorname{IR}\left(\mathrm{KBr}, \mathrm{cm}^{-1}\right)$ : 3,400, 3,264 $\left(\mathrm{NH}_{2}\right), 3,180(\mathrm{OH}), 2,892$ (CH-Imidazole), 1,709, 1,687 $(\mathrm{C}=\mathrm{N}), 1,687,1,469$ (benzene ring), 1,348 $(\mathrm{N}=\mathrm{O}), 1,220(\mathrm{C}-\mathrm{N}), 931(\mathrm{~N}-\mathrm{O})$.

Z-isomer: ${ }^{1} \mathrm{HNMR}\left(250 \mathrm{MHz}, \mathrm{DMSO}-d_{6}\right): 3.78(\mathrm{~s}, 3 \mathrm{H}$, $\mathrm{CH}_{3}$ ), 5.59 (s, H, CH-Imidazole), 6.38 (s, $\mathrm{H}, \mathrm{NH}_{2}$ ), 6.90-7.06 (m, H-Ar), 7.53 (s, H, NH), 10.2 (s, H, NOH) ppm; ${ }^{13} \mathrm{CNMR}\left(62.5 \mathrm{MHz}, \mathrm{DMSO}-d_{6}\right): 56.3,93.6,112.5$, $114.9,115.2,120.1,129.8,130.0,141.9,158.8$ ppm.

4-Amino-5-(hydroxyimino)-2-methyl-2,5-dihydro- $1 \mathrm{H}$ imidazole 3-oxide (3i)

(65\%) yellow solid, mp 237-239 ${ }^{\circ} \mathrm{C} ;{ }^{1} \mathrm{HNMR}(250 \mathrm{MHz}$, DMSO-d $)_{6}$ : 1.32-1.34 (d, $\left.3 \mathrm{H}, \mathrm{CH}_{3}\right), 3.36$ (q, H, CHImidazole), 6.32 (s, H, $\mathrm{NH}_{2}$ ), 7.24 (s, H, NH), 9.91 (s, H, $\mathrm{NOH}) \mathrm{ppm}$.

2-Amino-3-(hydroxyimino)-1,4-diazaspiro[4.4]non-1-ene 1-oxide (5a)

(90\%) white solid, mp $216{ }^{\circ} \mathrm{C}$; IR $\left(\mathrm{KBr}, \mathrm{cm}^{-1}\right): 3,443$, 3,324, 3,185, 1,714, 1,684, 1,466, 1,330, 1,193, 1,036, 959. 746. $\mathrm{Z}$ and $\mathrm{E}$ isomer: ${ }^{1} \mathrm{HNMR}\left(250 \mathrm{MHz}, \mathrm{DMSO}-d_{6}\right)$ : 
1.57-1.73 (m, 8H, Cyclopentane), 5.49, 6.38 (s, 2H, $\mathrm{NH}_{2}$ ), 7.14, 7.85 (s, H, NH), 9.92, 10.11 (s, H, NOH) ppm; ${ }^{13} \mathrm{CNMR}\left(62.5 \mathrm{MHz}, \mathrm{DMSO}-d_{6}\right): 23.4,25.1,36.9,38.2$, 91.0, 107.5, 136.4, 142.3, 144.4, $151.0 \mathrm{ppm}$.

Z-isomer: ${ }^{1} \mathrm{HNMR}\left(250 \mathrm{MHz}, \mathrm{DMSO}-d_{6}\right): 1.57-1.73$ (m, 8H, Cyclopentane), 6.39 (s, 2H, NH $), 7.85$ (s, H, NH), 9.92 (s, H, NOH), ppm; ${ }^{13} \mathrm{CNMR}\left(62.5 \mathrm{MHz}, \mathrm{DMSO}-d_{6}\right)$ : 24.5, 36.3, 90.5, 136.0, 143.9 ppm.

\section{2-Amino-3-(hydroxyimino)-1,4-diazaspiro[4.5]dec-1-ene- 1-oxide(5b)}

(95\%) white solid, $\mathrm{mp} 208-210{ }^{\circ} \mathrm{C}$; IR $\left(\mathrm{KBr}, \mathrm{cm}^{-1}\right)$ : $3,318,3,189,2,933,2,867,2,796,1,712,1,695,1,614$, $1,455,1,383,1,315,1,251,1,167,936,753$.

$\mathrm{Z}$ and $\mathrm{E}$ isomer: ${ }^{1} \mathrm{HNMR}$ (250 MHz, DMSO- $\left.d_{6}\right)$ : 1.19-1.67 (m, 10H, Cyclohexane) 5.47, $6.25\left(\mathrm{~s}, 2 \mathrm{H}, \mathrm{NH}_{2}\right)$, 6.94, 7.76 (s, H, NH), 9.91, 10.07 (s, H, NOH) ppm; ${ }^{13} \mathrm{CNMR}\left(62.5 \mathrm{MHz}, \mathrm{DMSO}-d_{6}\right): 21.2,22.4,24.1,24.3$, 34.7, 35.8, 83.2, 97.6, 135.5, 141.8, 143.7, 150.5 ppm.

Z-isomer: ${ }^{1} \mathrm{HNMR}$ (250 MHz, DMSO- $d_{6}$ ): $1.19-2.08$ (m, 10H, cyclohexane) $5.47\left(\mathrm{~s}, 2 \mathrm{H}, \mathrm{NH}_{2}\right), 6.94(\mathrm{~s}, \mathrm{H}, \mathrm{NH})$, 10.04 (s, H, NOH) ppm; ${ }^{13} \mathrm{CNMR}\left(62.5 \mathrm{MHz}, \mathrm{DMSO}-d_{6}\right)$ : 22.4, 24.3, 35.8, 97.6, 141.8, 150.5 ppm.

2-Amino-3-(hydroxyimino)-1, 4-diazaspiro[4.6]undec-1ene-1-oxide (5c)

(88\%) white solid, mp $163{ }^{\circ} \mathrm{C}$; IR $\left(\mathrm{KBr}, \mathrm{cm}^{-1}\right): 3,374$, 3,152, 2,923, 1,684, 1,574, 1,459, 1,317, 1,273, 1,205, 945, 912,746

$\mathrm{Z}$ and $\mathrm{E}$ isomer: ${ }^{1} \mathrm{HNMR}$ (250 MHz, DMSO- $\left.d_{6}\right)$ : 1.52-2.16 (m, 12H, Cycloheptane), 5.45, 6.23 (s, 2H, $\mathrm{NH}_{2}$ ) , 7.06, 7.77 (s, H, NH), 9.87, 10.05 (s, H, NOH) ppm. ${ }^{13}$ CNMR (62.5 MHz, DMSO- $d_{6}$ ): 21.3, 21.8, 29.0, 29.7, 39.5, 39.6, 80.5, 101.8, 125.5, 141.9, 144.6, 150.4 ppm.

Z-isomer: ${ }^{1} \mathrm{HNMR}$ (250 MHz, DMSO-d $)$ ): 1.61-2.32 (m, 12H, Cycloheptane), 6.26(s, 2H, $\left.\mathrm{NH}_{2}\right), 7.79$ (s, H, NH), 10.06 (s, H, NOH) ppm. ${ }^{13} \mathrm{CNMR}\left(62.5 \mathrm{MHz}, \mathrm{DMSO}-d_{6}\right)$ : 21.8, 29.7, 39.5, 101.8, 141.9, 150.4 ppm.

\section{2-Amino-8-tert-butyl-3-(hydroxyimino)-1, 4-diazaspiro[4.5]dec-1-ene 1-oxide(5d)}

(92\%) white solid, mp $220^{\circ} \mathrm{C}$; IR $\left(\mathrm{KBr}, \mathrm{cm}^{-1}\right): 3,585$, $3,257,2,954,2,867,1,690,1,478,1,368,1,304,1,249$, 1,194, 1,133, 946, 748 .

$\mathrm{Z}$ and $\mathrm{E}$ isomer: ${ }^{1} \mathrm{HNMR}\left(250 \mathrm{MHz}, \mathrm{DMSO}-d_{6}\right): 0.84$, 0.86 (s, 9H, m, Tert-butyl), 1.28 (p, 1H,CH-cyclohexane), 1.32-2.00 (m, 8H, Cyclohexane), 5.84, 6.27 (s, 2H, $\mathrm{NH}_{2}$ ), 7.35, 7.96 (s, H, NH), 9.86, 10.03 (s, H, NOH) ppm; ${ }^{13} \mathrm{CNMR}$ (62.5 MHz, DMSO- $\left.d_{6}\right)$ : 18.11, 23.28, 27.43,
$27.58,32.12,36.04,36.19,36.70,38.40,81.04,99.25$, 136.02, 138.8, 146.01, $150.16 \mathrm{ppm}$.

Z-isomer: ${ }^{1} \mathrm{HNMR}\left(250 \mathrm{MHz}, \mathrm{DMSO}-d_{6}\right): 0.88(\mathrm{~s}, 9 \mathrm{H}$, $\mathrm{m}$, Tert-butyl), 1.43 (p, 1H, cyclohexane), 1.39-2.11 (m, $8 \mathrm{H}$, Cyclohexane), 6.43 (s, 2H, $\left.\mathrm{NH}_{2}\right), 8.03$ (s, H, NH), 10.12 (s, H, NOH) ppm.

4-Amino-5-(hydroxyimino)-2,2-dimethyl-2,5-dihydro-1Himidazole 3-oxide(5e)

(85\%) white solid, mp $217^{\circ} \mathrm{C}$; $\operatorname{IR}\left(\mathrm{KBr}, \mathrm{cm}^{-1}\right): 3,460$, 3,357, 3,187, 2,765, 1,695, 1,636, 1,439, 1,315, 1,191, 947, 718. $\mathrm{Z}$ and E isomer: ${ }^{1} \mathrm{HNMR}\left(250 \mathrm{MHz}, \mathrm{DMSO}-d_{6}\right): 1.35$ $\left(\mathrm{s}, 6 \mathrm{H}, \mathrm{CH}_{3}\right), 5.48,6.24\left(\mathrm{~s}, 2 \mathrm{H}, \mathrm{NH}_{2}\right), 6.96,7.59(\mathrm{~s}, \mathrm{H}$, $\mathrm{NH}), 9.85,10.12$ (s, H, NOH) ppm; ${ }^{13} \mathrm{CNMR}(62.5 \mathrm{MHz}$, DMSO- $\left.d_{6}\right)$ : $25.9,26.5,81.0,97.0,135.0,141.8,143.9$, $150.5 \mathrm{ppm}$.

Z-isomer: ${ }^{1} \mathrm{HNMR}\left(250 \mathrm{MHz}, \mathrm{DMSO}-d_{6}\right): 1.39(\mathrm{~s}, 6 \mathrm{H}$, $\mathrm{CH}_{3}$ ), 6.34 (s, 2H, $\mathrm{NH}_{2}$ ), 7.64 (s, H, NH), 10.16 (s, H, $\mathrm{NOH}) \mathrm{ppm} ;{ }^{13} \mathrm{CNMR}\left(62.5 \mathrm{MHz}, \mathrm{DMSO}-d_{6}\right): 26.1,97.3$, 142.0, 150.8 ppm.

Open Access This article is distributed under the terms of the Creative Commons Attribution License which permits any use, distribution, and reproduction in any medium, provided the original author(s) and the source are credited.

\section{References}

1. E. Colacino, P. Nun, F.M. Colacino, J. Martinez, Tetrahedron 64, 5569 (2008)

2. D. St. C. Black, R. F. Crozier, V. C. Davis, Synthesis 205 (1975)

3. A. Padwa, Angew. Chem., Int Ed Engl 15, 123 (1976)

4. W. Oppolzer, Angew Chem Int Ed Engl 16, 10 (1977)

5. C.P. Dell, J Chem Soc Perkin Trans 1, 3873 (1998)

6. N. Coskun, Turk J Chem 25, 267 (2001)

7. N. Coskun, F.T. Tat, Phosphorus Sulfur 178, 881 (2003)

8. N. Coskun, F.T. Tat, Turk J Chem 28, 1 (2004)

9. L.-C. Li, D.-Z. Liao, L.-J. Bai, Z.-H. Jiang, S.-P. Yan, J Mol Struct 569, 179 (2004)

10. M.A. Voinov, I.A. Grigorev, L.B.T. Volodarsky, Tetrahedron 56, $4071(2000)$

11. A.R. Green, T. Ashwood, T. Odergren, D.M. Jackson, Pharmacol Ther 100, 195 (2003)

12. N. Coskun, H. Mert, N. Arikan, Tetrahedron 62, 1351 (2006)

13. R.A. Floyd, Dieases Aging Cell 5, 51 (2006)

14. A. Banerji, A. Sahu, J Sci Ind Res 45, 355 (1986)

15. N. Coskun, D. Su Mengen, Synth Commun 23, 1699 (1993)

16. N. Coskun, Tetrahedron Lett 38, 2299 (1997)

17. N. Coskun, Tetrahedron 53, 13873 (1997)

18. N. Coskun, M. Ay, Heterocycles 48, 537 (1998)

19. N. Coskun, F.T. Tat, O.O. Gu-ven, D. lku, C. Arıcı, Tetrahedron Lett 41, 5407 (2000)

20. N. Coskun, F.T. Tat, O.O. Güven, Tetrahedron 57, 3413 (2001)

21. N. Coskun, F.T. Tat, O.O. Güven, Tetrahedron Asymmetry 12, 1463 (2001)

22. N. Coskun, H. Mert, N. Arikan, Tetrahedron 62, 1351 (2006)

23. N. Coskun, F.T. Tat, O.O. Güven, D. lkü, C. Arıcı, Tetrahedron Lett 41, 5407 (2000) 
24. N. Coskun, F.T. Tat, O.O. Güven, Tetrahedron 57, 3413 (2001)

25. S.A. Popov, R.V. Andreev, G.V. Romanenko, V.I. Ovcharenko, V.A. Reznikov, J Mol Struct 49, 697 (2004)

26. Y.B. Han, B. Tuccio, R. Lauricella, A. Rockenbauer, J.L. Zweier, F.A. Villamena, J Org Chem 73, 2533 (2008)
27. X.-Q. Cao, Z.-X. Li, G.-Q. Chen, D.-C. Zhang, Acta Cryst 63, $671(2007)$

28. X.-Q. Cao, Z.-X. Li, W.-X. Zhong, L.-H. Qiu, G.-Q. Chen, Heterocycles 78, 1445 (2009) 